\title{
Осмотично-об’ємний індекс сечі у виявленні та діагностуванні тяжкості центрального нецукрового діабету в нейрохірургічних хворих
}

\begin{abstract}
Мета роботи: дослідити зміни осмотично-об’ємного індексу сечі у хворих на нейрохірургічну патологію, ускладену центральним нецукровим діабетом, установити його цифрові значення залежно від ступеня тяжкості патології.

Матеріали і методи. Обстежено та проведено ретроспективне дослідження медичної документації у 52 нейрохірургічних пацієнтів, які перенесли черепно-мозкову травму (24), операцію з приводу пухлини мозку (14) та інсульту (14). Перебіг захворювання у них ускладнився центральним нецукровим діабетом різного ступеня тяжкості. Групу порівняння склали 20 нейрохірургічних хворих, у яких не відмічали нецукровий діабет. За показниками темпу діурезу та щільності сечі розробили інформаційний критерій діагностики нецукрового діабету та його тяжкості - осмотично-об’ємний індекс сечі.

Результати досліджень та ї обговорення. У фізіологічних умовах з організму людини впродовж години зазвичай виділяється 0,8-1,0 мл·кг-1 сечі. При цьому їі щільність складає 1012-1025. Вимірявши темп діурезу та щільність сечі та розрахувавши за наведеною формулою у 20 пацієнтів групи порівняння осмотично-об'ємний індекс сечі, установили середні його значення: 8,0-12,0. При центральному нецукровому діабеті осмотично-об'ємний індекс сечі різко знижується, набуваючи значень $<1,0$. Установили, що при нецукровому діабеті легкого ступеня осмотично-об’ємний індекс сечі складає 0,6-0,41, середнього - 0,4-0,21, а тяжкого - <0,2-0,05. Показником ефективності інтенсивної терапії нецукрового діабету є зростання осмотично-об’ємного індексу сечі до норми.

Для ранньої діагностики центрального нецукрового діабету у нейрохірургічних хворих доцільно проводити одночасне дослідження темпу діурезу і щільності сечі, за якими розраховувати осмотично-об’ємний індекс сечі згідно з запропонованою формулою. У нормі осмотично-об'ємний індекс сечі знаходиться в діапазоні значень 8,0-12,0. При центральному нецукровому діабеті легкого ступеня осмотично-об'ємний індекс сечі знижується до 0,6-0,41, середнього - до 0,4-0,21, а тяжкого - до 0,2-0,05.

Ознакою ефективності інтенсивної терапії хворого на центральний нецукровий діабет є зростання осмотично-об'ємного індексу сечі >1,0 у кожній із дослідних порцій сечі.
\end{abstract}

Ключові слова: нейрохірургя; центральний нецукровий діабет; щільність сечі; темп діурезу; гомеостаз; осмотично-об’ємний індекс сечі.

Постановка проблеми і аналіз останніх досліджень та публікацій. Центральний нецукровий діабет - тяжке ускладнення, яке виникає у понад 30 \% нейрохірургічних хворих при ураженнях гіпоталамо-гіпофізарної ділянки, зумовлених черепно-мозковими травмами, операційними втручаннями, пухлинами, а також у результаті значних ішемічних та гіпоксичних ушкоджень головного мозку [1].

Патогенез нецукрового діабету зумовлений порушеннями секреції або дії аргінін-вазопресину, який забезпечує регуляцію водно-електролітної рівноваги як відповідь на зміни осмолярності та об’єму циркулюючої крові. При розладах цього механізму спостерігається надмірне виділення сечі (понад 3 л•добу ${ }^{-1}$ ) низької щільності; виникає зневоднювання усіх секторів організму, гіпернатріємія та спрага [2]. Порушується один із основних законів гомеостазу - закон ізоосмолярності, що призводить до загальної та, особливо, внутрішньоклітинної гіпогідратації, як наслідок органних ушкоджень.

Як стверджує ряд авторів [3], у багатьох випадках серед персоналу нейрохірургічних клінік та відділень інтенсивної терапії відсутня настороженість щодо розвитку критичних порушень осмолярності у хворих із церебральною комою. Часто діагноз: центральний нецукровий діабет - виставляють тоді, коли у пацієнтів розвивається критична гіпернатріємія та гіперосмолярна гіпогідратація, яка призводить до внутрішньоклітинних розладів. Разом із тим, моніторинг осмотичних показників сечі та іï об’єму у хворих, які перебувають в стані церебральної коми, є ранніми маркерами ушкоджень регуляції гомеостазу організму [4]. Він відіграє чи ненайважливішу роль у діагностиці та виборі правильної тактики лікування гострих травм і захворювань головного мозку [5].

Мета роботи: дослідити зміни осмотично-об'ємного індексу сечі (OOIC) у хворих на нейрохірургічну патологію, ускладнену центральним нецукровим діабетом, установити його цифрові значення залежно від ступеня тяжкості патології.

Матеріали і методи. У КЛ “Феофанія” обстежено 52 нейрохірургічних пацієнтів (із них 38 - ретроспективно), які перенесли черепно-мозкову травму (24), операцію з приводу пухлини моз- 


\section{З ДОСВІДУ РОБОТИ}

ку (14) та інсульту (14). Перебіг захворювання у хворих ускладнився центральним нецукровим діабетом. При цьому у 24 хворих діагностовано нецукровий діабет легкого, у 18 - середнього та 10 - тяжкого ступеня. У 20 хворих (група порівняння) нецукрового діабету не було; водно-електролітних порушень плазми крові у них не спостерігали.

При центральному нецукровому діабеті перші ознаки патології можна виявити при дослідженні сечі; порушення осмолярності крові розвиваються значно пізніше та свідчать про наявність грубих функціональних та структурних змін [4].

Для раннього розпізнавання порушень осмолярності має значення як об’єм виведеної з організму сечі впродовж певного часу (темп діурезу), так і концентрація солей у цій порції сечі. При нецукровому діабеті суттєво зростає діурез на тлі затримки солей в організмі: розвивається гіпертонічна гіпогідратація, внаслідок чого із клітин виводиться вода.

При нецукровому діабеті спостерігається зростання діурезу понад норму: легкого ступеня 4-6, середнього - 8-12, а тяжкого - до 16 л/добу [2].

Одночасне вимірювання осмолярності сечі та іï об'єму, що виділяється з організму впродовж години, ми розробили критерій діагностики центрального нецукрового діабету - осмотично-об’ємний індекс сечі (OOIC).

$$
\text { OOIC }=\frac{(Щ С-1000) \cdot 100}{3 \cdot \text { Угод }},
$$

де ООІС - осмотично-об’ємний індекс сечі,

ЩС - щільність сечі, г/л

Vгод - темп діурезу (об’єм сечі, в мл, виділеної з організму впродовж години).

Темп діурезу можна оцінити так: виміряти об'єм сечі, виділеної через сечовий катетер впродовж години, або ж зібрати порцію сечі, виведеної з організму хворого впродовж певного часу, та розрахувати середній показник об’єму сечі, що виділяється за годину.

Щільність сечі у нормі сягає від 1012 до 1025 г/л [4]. Ї̈̈ найзручніше вимірювати за допомогою рефрактометра Аббе - візуального оптичного пристрою, який дає змогу визначати показник заломлення рідин. Принцип дії рефрактометра полягає у вимірюванні граничного кута заломлення на плоскій межі розділу двох прозорих середовищ (дослідного і відомого) при проходженні світла із середовища з меншим показником заломлення у середовище з більшим його показником [6] (рис. 1).

Для вимірювання щільності сечі пацієнта можна використати портативний медичний

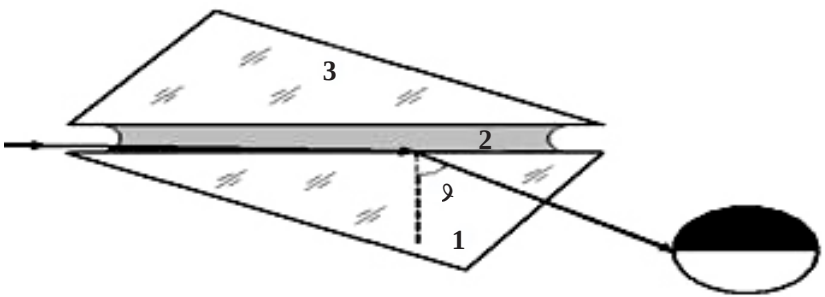

Рис. 1. Принцип рефрактометричного вимірювання щільності рідини.

рефрактометр. Для проведення такого вимірювання необхідно усього декілька крапель сечі, а саме дослідження триває кілька секунд (рис. 2).

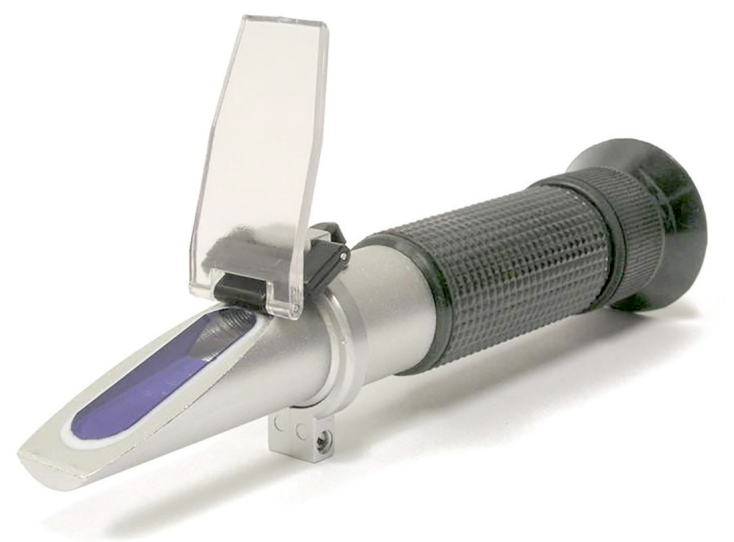

Рис. 2. Портативний медичний рефрактометр для вимірювання питомої густини сечі, плазми крові і білка сироватки крові.

Характеристика рефрактометра.

Показник заломлення: діапазон: 1.3330 1.3600 RI з роздільною здатністю 0,00025 RI і точністю $\pm 0,00025$ RI.

Рефрактометрично можна виміряти питому вагу сечі у діапазоні: 1.000 - 1.050 SG (urine specific gravity), з роздільною здатністю 0.002 SG i точністю $\pm 0,002$ SG.

При вимірюваннях відбувається автоматична температурна компенсація в межах від 10 до $30^{\circ} \mathrm{C}$.

Методика дослідження. Сечу (2-3 краплі) піпеткою наносять на поверхню лінзи рефрактометра i, спрямувавши її на джерело світла, спостерігають крізь окуляр. Світло, проходячи через призму, заломлюється у водному розчині. У видимому полі окуляра виділяється чітка границя між світлим і темним полями, розташована на градуйованій шкалі. За розміщенням цієї границі відносно цифрових значень шкали й визначається щільність сечі. 


\section{З ДОСВІДУ РОБОТИ}

Для отримання результату аналізу не потрібно клінічної лабораторії; рефрактометричне дослідження щільності сечі можна провести безпосередньо біля ліжка хворого.

При використанні калькулятора обчислення ООІС за наведеною формулою не становить жодних труднощів.

Результати досліджень та їх обговорення. У нейрохірургічних хворих групи порівняння, $\mathrm{y}$ яких не було нецукрового діабету, осмолярність плазми крові знаходилася в межах норми. Впродовж усього періоду спостережень погодинний темп діурезу у них становив 60-80 мл, а у кожній порції сечі її щільність - 1016 - 1022 г/л.

Приклад розрахунку ООІС у хворого О. з групи порівняння:

$$
\begin{aligned}
& \text { ЩС }=1022, \text { Угод }=75 \text { мл/год. } \\
& \text { OOIC }=\frac{(1022-1000) \cdot 100}{3 \cdot 75}=\frac{2200}{240}=9,8
\end{aligned}
$$

Встановлено, що в усіх хворих групи порівняння показник OOIC знаходився у діапазоні значень $8,0-12,0(10,0 \pm 0,5)$.

При цьому індикатором надмірного споживання води хворими або проведення їм понаднормової інфузійної терапії виступає зниження осмотично-об' ємного індексу сечі < 8,0. I навпаки, при дефіциті об'єму циркулюючої крові або недостатніх об'ємах інфузій він зростає $>12,0$.

У хворих на нецукровий діабет внаслідок порушень секреції або дії антидіуретичного гормону відбувається одночасне зростання як об'єму погодинного діурезу, так і зниження осмолярності сечі [7]. Встановлено, що при цьому показник осмотично-об'ємного індексу сечі різко знижується, сягаючи значень $<1,0$.

При побудові системи координат із відображенням на осі абсцис темпу діурезу, а на осі ординат - щільності сечі, можна отримати наочне зображення зсуву показників ООІС при центральному нецукровому діабеті - вправо і вниз - відносно норми (рис. 3).

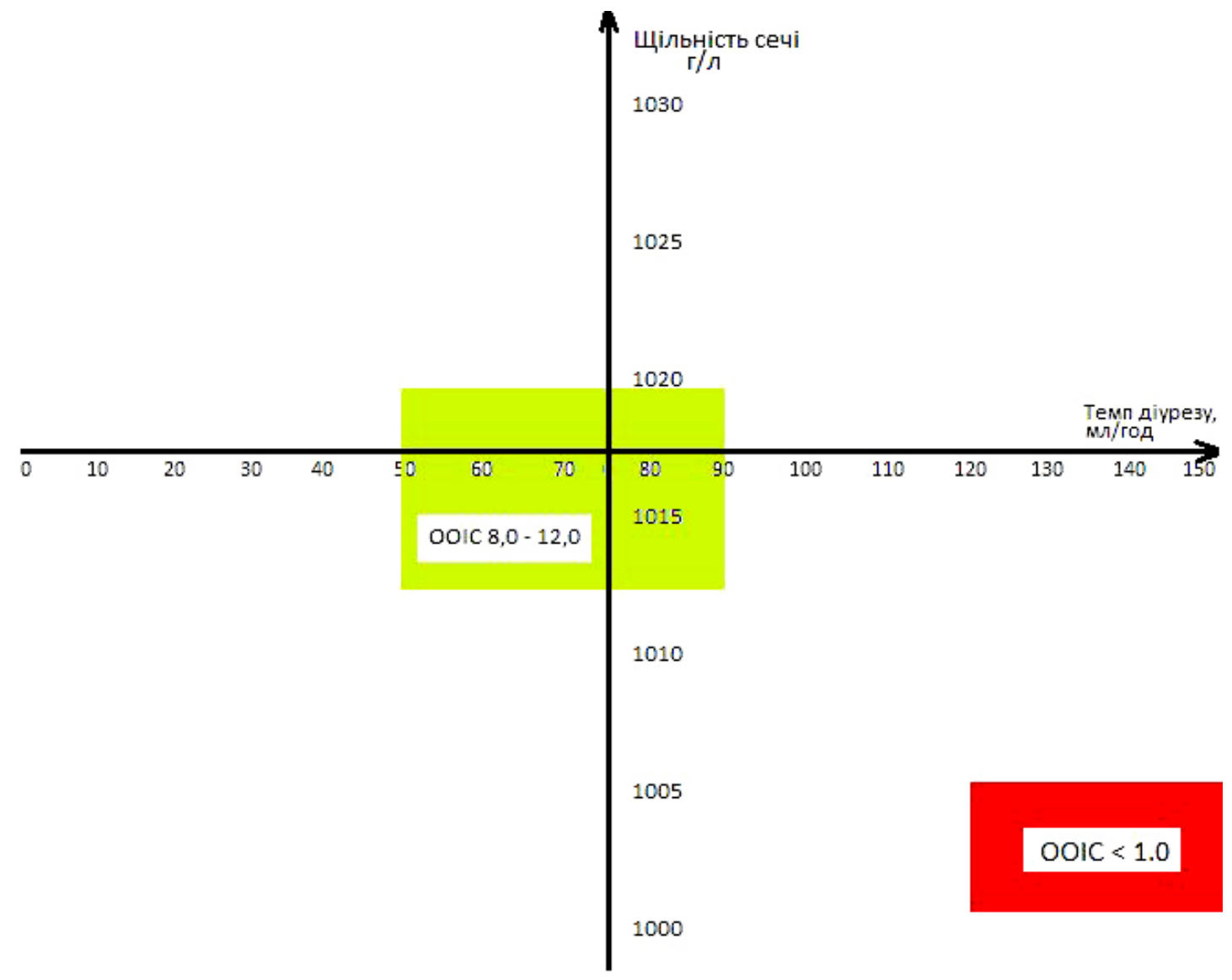

Рис. 3. Центральний нецукровий діабет у нейрохірургічних пацієнтів. Зміщення показників осмотично-об'ємного індексу сечі $(\mathrm{OOIC}<1,0)$ відносно норми (OOIC 8,0-12,0). 
Висока точність результатів досліджень зумовлена різнонаправленими зсувами патологічних змін при нецукровому діабеті: зниженням щільності сечі - у формулі вона відображена у числівнику, та зростанням об'єму сечі, виділеної впродовж години. Останнє відображено у знаменнику.

Особливості змін ООІС у хворих на нецукровий діабет різного ступеня тяжкості, порівняно 3 нормою, відображено в таблиці.

При застосуванні такого способу досліджень та обчислень OОIC за наведеною формулою чут- ливість діагностування центрального нецукрового діабету складає 100 \%, специфічність - 100 \%, точність $-100 \%$.

Загальні принципи інтенсивної терапії хворих на центральний нецукровий діабет полягають у проведенні інфузійної терапії гіпоосмолярними розчинами, перорального застосування води, а також за показаннями введення десмопресину [8].

Ознакою ефективності лікування є зростання ООІС понад 1,0 - до показників норми - 8,0-12,0.

Таблиця. Осмотично-об'ємний індекс сечі у хворих на нейрохірургічну патологію, ускладену нецукровим

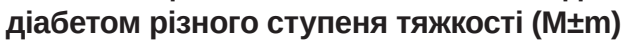

\begin{tabular}{|c|c|c|c|c|}
\hline & \multirow{2}{*}{ У нормі } & \multicolumn{3}{|c|}{ При нецукровому діабеті за ступенем тяжкості } \\
\hline & & легкого & середнього & тяжкого \\
\hline Щільність сечі, г/л & $1018,2 \pm 1,5$ & $1004,0 \pm 1,0 *$ & $1002,4 \pm 1,3^{*}$ & $1002,0 \pm 1,2 *$ \\
\hline Діапазон значень щільності сечі , г/л & 1016-1022 & $<1005^{*}$ & $<1005^{*}$ & $<1005^{*}$ \\
\hline Об’єм сечовиділення, л/добу & $1,5-2,5$ & $4,9 \pm 0,3^{*}$ & $9,3 \pm 0,5^{*}$ & $13,5 \pm 1,0 *$ \\
\hline Осмотично-об’ємний індекс сечі, од. & $9,8 \pm 0,3$ & $0,4 \pm 0,2^{*}$ & $0,2 \pm 0,1^{*}$ & $0,1 \pm 0,04^{*}$ \\
\hline $\begin{array}{l}\text { Діапазон значень осмотично- } \\
\text { об’ємного індексу сечі, од. }\end{array}$ & $8,0-12,0$ & $0,66-0,41^{*}$ & $0,4-0,21 *$ & $0,2-0,05 *$ \\
\hline
\end{tabular}

Примітка. * - p <0,001 порівняно з нормою.

Висновки. Для ранньої діагностики центрального нецукрового діабету у нейрохірургічних хворих доцільно проводити одночасне дослідження темпу діурезу і щільності сечі, за якими розраховувати осмотично-об'ємний індекс сечі відповідно до запропонованої формули.

\section{СПИСОК ЛІТЕРАТУРИ}

1. Diabetes insipidus after traumatic brain injury / C. Capatina, A. Paluzzi, R. Mitchell, N. Karavitaki // J. Clin. Med. - 2015. Vol. 4. - P. 1448-1462.

2. Дзеранова Л. К. Несахарный диабет. В кн. Эндокринология. Национальное руководство / Л. К. Дзеранова, Е. А. Пигарова ; ред. И. И. Дедов, Г. А. Мельниченко. - 2-е изд. - Москва : ГЭОТАР Медиа. - 2016. - С. 804-809.

3. Лукьянчиков В. С. Несахарный диабет и коморбидные нарушения водно-электролитного обмена / В. С. Лукьянчиков // Медицинский совет. - 2017. - № 3. С. 89-94.

4. Вікуліна Г. В. Діагностичне значення деяких біохімічних індексів крові та сечі / Г. В. Вікуліна, С. Б. Боровков // Вісник Полтавської державної аграрної академії. - 2017. - № 3. - C. $118-121$.
У нормі ООIC знаходиться у діапазоні значень 8,0-12,0. При центральному нецукровому діабеті легкого ступеня ООІС знижується до 0,66-0,41, середнього - до 0,4-0,21, а тяжкого - до 0,2-0,05.

Ознакою ефективності інтенсивної терапії хворого на центральний нецукровий діабет є зростання ОOІС>1,0 у кожній із дослідних порцій сечі.

5. Анциферов М. Б. Центральный несахарный диабет: современные представления и лечебные подходы / М. Б. Анциферов, Н. В. Маркина // Фарматека. - 2011. - № 3. - С. 60-64. 6. Иоффе Б. В. Рефрактометрические методы химии / Б. В. Иоффе. - 3 изд. - Ленинград, 1983.

7. Медведев В. В. Клиническая лабораторная диагностика: справочник для врачей / В. В. Медведев, Ю. 3. Волчек. - СПб., 1995.

8. Назаренко Г. И. Клиническая оценка лабораторных исследований / Г. И. Назаренко, А. А. Кишкун. - М., 2002.

9. Пигарова Е. А., Рожинская Л. Я. Лечение центральной формы несахарного диабета вследствие нейросаркоидоза / Е. А. Пигарова, Л. Я. Рожинская // Эффективная фармакотерапия. - 2015. - № 7. С. 20-26. 


\section{З ДОСВІДУ РОБОТИ}

\section{REFERENCES}

1. Capatina, C., Paluzzi, A., Mitchell, R., \& Karavitaki, N. (2015). Diabetes insipidus after traumatic brain injury. J. Clin. Med., 4, 1448-1462.

2. Dzeranova, L.K., \& Pigarova, E.A. (2016). Nesakharniy diabet $v \mathrm{kn}$. Endocrinologiya. Natsionalnoe rukovodstvo [Diabetes insipidus. In the book. Endocrinology. National leadership]. Dedov, I.I., \& Melnichenko, G.A. (Eds.). Moscow: GEOTAR Media [in Russian].

3. Lucyanchikov, V.S. (2017). Nesaharniy diabet i komorbidnye narusheniya vodno-elektrolitnogo obmena [Diabetes insipidus and comorbid disorders of water-electrolyte metabolism]. $\mathrm{Me}$ ditsinskiy sovet - Medical Council, 3, 89-94 [in Russian].

4. Vikulina, G.V., \& Borovkov, S.B. (2017). Diagnostychne znachennia deiakykh biokhimichnykh indeksiv krovi ta sechi [Diagnostic value of some biochemical indices of blood and urine]. Visnyk Poltavskoi derzhavnoi ahrarnoi akademii - Bulletin of the Poltava State Agrarian Academy, 3, 118-121 [in Ukrainian].

Електронна адреса для листування: Gnativ_y@meta.ua
5. Ancuferov, M.B., \& Markina, N.V. (2011). Tsentralniy nesaharniy diabet: sovremennie predstavleniya i lechebnye podkhody [Central diabetes insipidus: modern concepts and treatment approaches]. Farmateka, 3, 60-64 [in Russian].

6. Ioffe, B.V. (1983). Refraktometricheskie metody himii [Refractometric chemistry methods]. Leningrad [in Russian].

7. Medvedev, V.V., \& Volchek, Yu.Z. (1995). Klinicheskaya laboratornaya diagnostika: Spravochnik dlya vrachey [Clinical laboratory diagnostics: A handbook for physicians] [in Russian]. 8. Nazarenko, G.I., \& Kishkun, A.A. (2002). Klinicheskaya otsenka laboratornykh issledovaniy [Clinical evaluation of laboratory tests]. Moscow [in Russian].

9. Pigarova, E.A., \& Rozhunskaya, L.Ya. (2015). Lechenie tsentralnoy formy nesaharnogo diabeta vsledstvie neyrosarkoidoza [Treatment of central diabetes insipidus due to neurosarcoidosis]. Effektivnaya farmakoterapiya - Effective Pharmacotherapy, 7, 20-26 [in Russian].

\section{OSMOTICALLY VOLUMETRIC URINE INDEX IN THE DETECTION AND DIAGNOSIS OF THE SEVERITY OF CENTRAL DIABETES INSIPIDUS IN NEUROSURGICAL PATIENTS}

The aim of the work: to study the changes of osmotically volumetric urine index (OVUI) in patients with central diabetes insipidus and to establish its digital values at the different severity degree of the pathology.

Materials and Methods. Medical records of 52 neurosurgical patients with craniocerebral trauma (24), brain tumor operation (14) and stroke (14) s were retrospectively examined and the course of their disease was complicated by central diabetes insipidus of different severity. The comparison group consisted of 20 neurosurgical patients who had no diabetes insipidus. We developed an informative criterion of diabetes insipidus diagnosis and its severity: OVUI behind the indices of diuresis rate and urine density.

Results and Discussion. Normal hourly diuresis is $0.8-1.0 \mathrm{ml} \cdot \mathrm{kg}-1$ of urine. Its density is $1012-1025$. Having measured diuresis rate and urine density in 20 patients of the comparison group, we calculated it according to the above formula and found its average values: 8.0-12.0. In central diabetes insipidus the OVUI drops sharply $<1.0$. We found that in mild diabetes insipidus, the OVUI is $0.66-0.41$, moderate $-0.4-0.21$, and severe $-<0.2-0.05$. An indicator of the adequacy of intensive therapy for diabetes insipidus is the increase of OVUI to normal. For early diagnosis of central diabetes insipidus in neurosurgical patients, it is advisable to conduct a simultaneous study the rate of diuresis and urine density, which are used to calculate the OVUI according to the proposed formula. Normally, the OVUI is in the range of 8.0-12.0. In central diabetes insipidus, the OVUI decreases to 0.6-0.41, moderate - to $0.4-0.21$, and severe - to $0.2-0.05$. A sign of the effectiveness of intensive care in patients with diabetes insipidus is an increase in the OVUI $>1.0$ in each of the experimental portions of urine.

Key words: neurosurgery; central diabetes insipidus; urine density; diuresis rate; homeostasis; urine index. 